Article

\title{
The Climatology of Significant Tornadoes in the Czech Republic
}

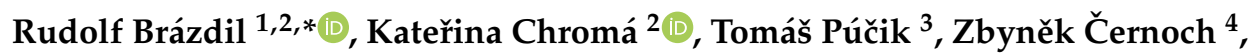 \\ Petr Dobrovolný ${ }^{1,2}$, Lukáš Dolák ${ }^{1,2}$, Oldřich Kotyza ${ }^{5}$, Ladislava Řezníčková ${ }^{1,2}$ \\ and Mateusz Taszarek ${ }^{6,7}$ \\ 1 Institute of Geography, Masaryk University, 61137 Brno, Czech Republic; dobro@sci.muni.cz (P.D.); \\ dolak@sci.muni.cz (L.D.); ladkar@sci.muni.cz (L.̌̌.) \\ 2 Global Change Research Institute, Czech Academy of Sciences, 60300 Brno, Czech Republic; \\ chroma.k@czechglobe.cz \\ 3 European Severe Storms Laboratory, 2700 Wiener Neustadt, Austria; tomas.pucik@essl.org \\ 4 Větřkovice 206, 74743 Větřkovice, Czech Republic; zbynekcernoch@seznam.cz \\ 5 Regional Museum, 41201 Litoměřice, Czech Republic; muzeum.ltm@telecom.cz \\ 6 Department of Meteorology and Climatology, Adam Mickiewicz University, 61-680 Poznań, Poland; \\ mateusz.taszarek@amu.edu.pl \\ 7 National Severe Storms Laboratory, Norman, OK 73072, USA \\ * Correspondence: brazdil@sci.muni.cz
}

Received: 1 June 2020; Accepted: 28 June 2020; Published: 29 June 2020

check for updates

\begin{abstract}
In the Czech Republic, tornadoes may reach an intensity of F2 and F3 on the Fujita scale, causing "considerable" to "severe" damage. Documentary evidence is sufficient to allow the creation of a chronology of such events, from the earliest recorded occurrence in 1119 CE (Common Era) to 2019, including a total of 108 proven or probable significant tornadoes on 90 separate days. Since only 11 significant tornadoes were documented before 1800, this basic analysis centers around the 1811-2019 period, during which 97 tornadoes were recorded. Their frequency of occurrence was at its highest in the 1921-1930, 1931-1940, and 2001-2010 decades. In terms of annual variations, they took place most frequently in July, June, and August (in order of frequency), while daily variation favored the afternoon and early evening hours. Conservative estimates of human casualties mention 8 fatalities and over 95 people injured. The most frequent types of damage were related to buildings, individual trees, and forests. Tornadoes of F2-F3 intensity were particularly associated with synoptic types characterized by airflow from the western quadrant together with troughs of low pressure extending or advancing over central Europe. Based on parameters calculated from the ERA-5 re-analysis for the period of 1979-2018, most of these tornadoes occurred over a wide range of Convective Available Potential Energy (CAPE) values and moderate-to-strong vertical wind shear. The discussion herein also addresses uncertainties in tornado selection from documentary data, the broader context of Czech significant tornadoes, and the environmental conditions surrounding their origins.
\end{abstract}

Keywords: tornado; documentary data; tornado intensity; tornado damage; tornado fatality; spatiotemporal variability; dynamic climatology; environmental conditions; Czech Republic

\section{Introduction}

Tornadoes are small-scale but severe weather phenomena involving extreme wind speeds and gusts strong enough to do a wide range of heavy material damage at local or regional scales. They may also lead to human casualties, including fatalities [1,2]. Although such events are commonly associated with the central U.S. [3,4] where their effects are particularly marked and feature higher levels of 
casualties (e.g., [5-8]), they also occur on other continents (e.g., [9,10]). In Europe (e.g., [11-14]), they may be considered natural disasters of high importance.

Speculation about the nature of tornadoes was already evident in Ancient Greece. Aristotle, in his Meteorologica (c. 340 Before the Common Era), proposed that the formation of tornadoes and waterspouts was associated with wind trapped within a cloud and moving in a circular fashion [15]. Although tornadoes and waterspouts were observed and recorded many times in the course of the past millennium, and the German scientist Alfred Wegener published the book Wind- und Wasserhosen in Europa (Tornadoes and Waterspouts in Europe) as early as 1917 [16], tornadoes remained beyond the mainstream interests of European meteorologists and climatologists for many decades, despite a number of local descriptions of particular events (e.g., [17-19]) and even the first attempts at chronologies (e.g., [20-23]). The situation changed quite abruptly in the 1990s-2000s, when various aspects of tornadoes started to attract serious and more widespread research activities in Europe (e.g., [11,24]).

Recent investigations in Europe have taken several different points of departure: the environmental conditions surrounding them (e.g., [25-29]), comprehensive analyses of individual events (e.g., [30-36]), climatology (e.g., [12,37-41]), and the creation and updating of long-term tornado chronologies among them (e.g., [42-47]). Antonescu et al. [48] summarized the considerable development of tornado research at national levels in many European countries, mentioning 9563 tornadoes in 30 countries recorded during the 1800-2014 period.

Reflections of the general burgeoning of tornado research in Europe may also be found at the scale of the Czech Republic. First to appear were papers describing individual examples of such phenomena without using the term "tornado" (e.g., [49-51]). Pech [52] was probably the first to use this term in reference to the tornado event on 18 July 1966 in the Všerubská vrchovina Highlands. Further steps in tornado research were taken by the papers by Munzar in the 1990s [53,54], and then, in particular, through the activities of researchers around Martin Setvák from the Czech Hydrometeorological Institute (CHMI) in the late 1990s. Examples of tornadoes as a topic of systematic interest may be found in a number of papers originating with the latter group (e.g., [55-57]). A chronology developed by Setvák et al. [58] was progressively and significantly extended by researchers from Masaryk University, Brno, as one of the outcomes of their broader historical-climatological research. Tornadoes became a part of their analyses of strong winds in the Czech Lands $[59,60]$ and considerably extended tornado chronologies for the Czech Republic were analyzed and published by Brázdil et al. [61,62].

This study aims to analyze significant tornadoes, judged by their damage intensity (categorized as F2 and F3 on the Fujita scale), to be recorded throughout the Czech Republic. The analysis addresses their spatiotemporal variability, material damage and casualties done, dynamic climatology, and the environmental conditions associated with them. This paper is an extension of work already published by Brázdil et al. [61,62]. Section 2 presents the documentary and meteorological data employed in this study and describes approaches to their analysis. Section 3 describes the results of statistical analysis of significant tornadoes with respect to their spatiotemporal variability, damage and casualties, dynamic climatology, and environmental conditions. Section 4 is dedicated to data uncertainties and the broader context of the results obtained. It is followed by some summarizing conclusions.

\section{Material and Methods}

\subsection{The Study Area}

The Czech Republic (Figure 1) is located in central Europe and extends over a territory of $78,870 \mathrm{~km}^{2}$. As a state unit, it emerged in 1993 from what had been Czechoslovakia. Czechoslovakia was established in 1918 after the post-WWI disintegration of the Austro-Hungarian Empire (the Czech Lands had previously been provinces of its Austrian part). The Czech Republic consists of Bohemia in the western part and Moravia and Silesia in the east. Sněžka Mt. (1603 m a.s.l.), in the Krkonoše Mountains to the north, is the highest point in the Czech Republic and the lowest, near Hřensko (115 $\mathrm{m}$ a.s.1.) is in the north-west, where the River Elbe leaves Bohemia. The mean altitude of the 
country is $450 \mathrm{~m}$. Climatic data for 1981-2018 indicate that the mean annual temperature is $8.1^{\circ} \mathrm{C}$ (from $1.7^{\circ} \mathrm{C}$ to $10.9^{\circ} \mathrm{C}$ ) and mean annual precipitation $692 \mathrm{~mm}$ (from $442 \mathrm{~mm}$ to $1467 \mathrm{~mm}$ ). The annual temperature variation exhibits a simple wave with a minimum in January and a maximum in July. Annual precipitation distribution has a minimum in February and a maximum in July, with several secondary minima and maxima [63].

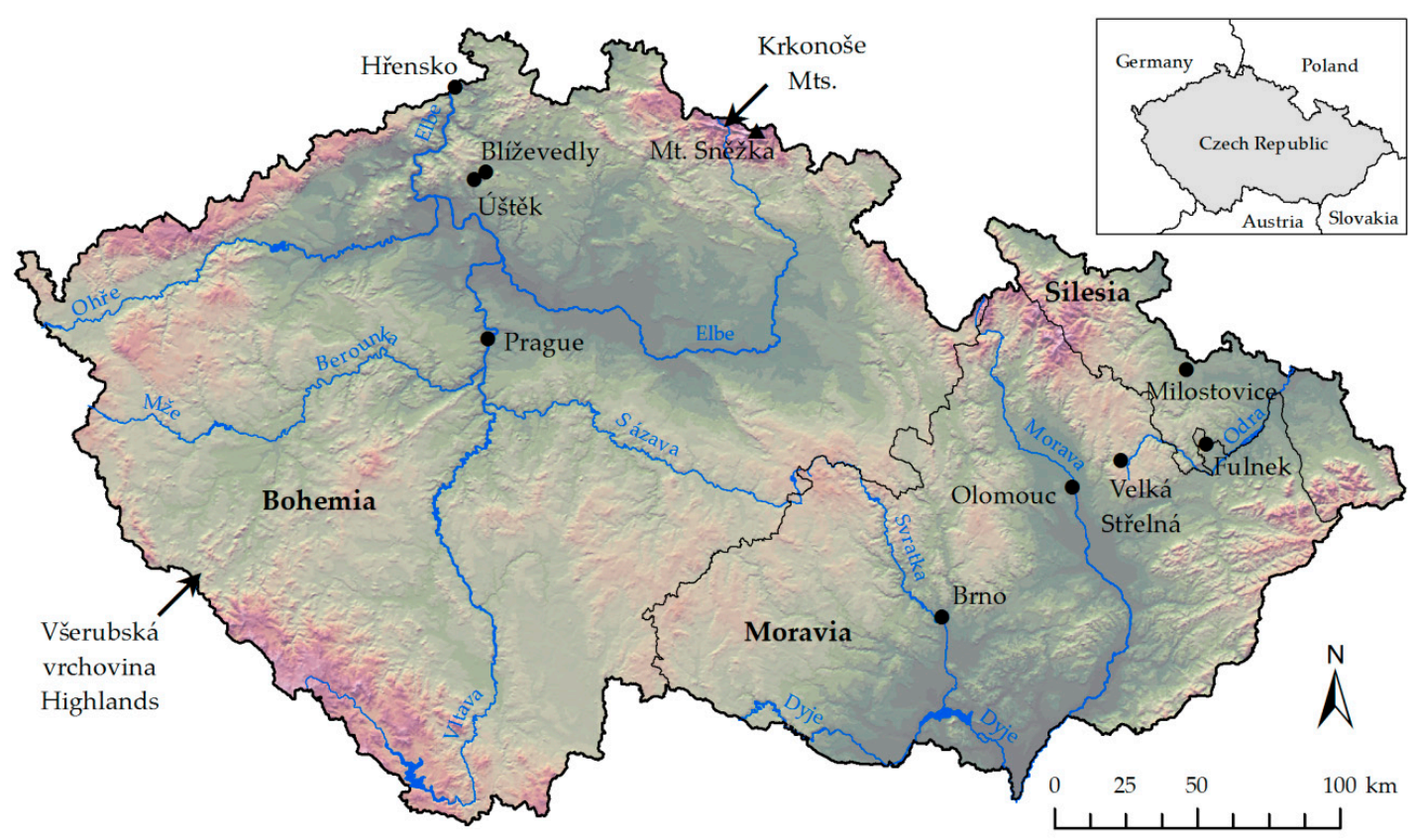

Figure 1. Map of the Czech Republic and its position in central Europe, together with locations mentioned in this paper.

\subsection{Documentary Data}

The local-to-regional scale of tornadoes, together with their discontinuous and patchy occurrence, precludes their systematic observation within the basic network of the meteorological stations of the CHMI. The distances between individual meteorological stations are such that tornadoes may well occur "officially" unnoticed. In this situation, their presence tends to be reflected in documentary sources of various kinds that facilitate the creation of datasets of information about weather and related phenomena as the basic platform for historical climatology [64,65]. Information about tornadoes has to be derived from a range of documentary sources that contain indications and descriptions of events of interest (narrative sources such as annals, diaries and chronicles, taxation reports, newspapers, reports published by scientific societies, pictorial evidence, special reports, and websites-see [62]). Tornado data already collected for other publications [61,62] have been extended herein by further searches within documentary sources, particularly newspapers.

Tornado-related events may usually be found through reference to the German terms Windhose, Trombe, and Wirbelwind or, in Czech, smršt', tromba or cyklon. However, more important than the appearance of these terms in reports are the direct descriptions of observed wind phenomena that include their impacts or consequences and permit the interpretation of such phenomena as "probable" or "proven" tornadoes on the one hand and their classification in terms of intensity according to the largely damage-based Fujita scale [66,67] on the other. The Fujita scale, classifying tornadoes from F0 ("light") to F5 ("incredible") has been favored over other tornado intensity scales herein. Other available scales included, for example, the TORRO scale [68,69] and the enhanced Fujita scale [70]. The choice of the Fujita scale maintains consistency with other Czech contributions [61,62]. F2 is considered a "significant" tornado on the Fujita scale, and F3 is "severe". Moreover, a transitional category (F2-F3) is employed herein, although it does not appear in the original Fujita scale. 
Tornadoes are classified herein as "probable" when damage reports suggests tornado occurrence, but there is no direct record of the accompanying phenomena. The description of an event on 5 July 1916 that took place in the village of Velká Střelná (now defunct) serves as an example of a "probable" tornado of F2-F3 intensity [71]: "[ ... ] in the afternoon at half-past four [everything] suddenly went black. The whole village was within a large, single dust-cloud, a strong wind rumbled, [and] all that could be heard was the cracking of branches, which [then] flew through the air, knocked from the trees as if someone had lopped them off; thick trees - lindens, maples, ash-were torn out of the soil or snapped in two like twigs; stones, slates, and shingles from ruined chimneys, roofs and barns flew through the air. The whirlwind ["smršt'"] continued for only a few minutes, then thunder and rain followed. Uprooted trees pierced the roofs of several houses. The gale tore away both sides of the parish barn, leaving its bricked gables [down] to a length of several meters. Flying stones and shingles broke windows on the first floor of the vicarage [ ... ]".

"Proven" tornadoes are classified as cases in which-as well as the typically short duration and the character of damage-appropriate atmospheric phenomena were described. For example, an event on 21 June 1932 that took place in Milostovice was classified as a "proven" tornado of F3 intensity [72]: "This day around six a clock in the afternoon [... ] it became suddenly dark. Heavy black clouds rushed from the south and the north to the eastern periphery of the village. At the moment the clouds crashed [into one another], they began to fall rapidly to earth and created a cone-shaped column; its top smashed heavy clouds. Thus, the column created, rotating extraordinarily quickly, appeared fiery and shining. [ ... ] In a second the column became covered in a foggy, whirling veil and then a whirl of wind rose up, accompanied a by dull roar. This lasted only a short moment-perhaps a minute-and everywhere the whirl went it reduced everything to debris and havoc. [ ... ] Leopold Cigánek's new barn was blown to pieces and only remnants of [its] brick pillars remained. The roof was carried c. $50 \mathrm{~m}$ and crashed onto Vojtěch Šafránek's shed. The iron pump on the water-well was twisted off by the whirlwind ["cyklon"] and thrown over a 2-m gate on the road. A cast-iron hay tedder, standing in the meadow, was carried c. $40 \mathrm{~m}$ by strong wind and then rammed into the pillar of a gate [... ] Windows, together with their frames, and doors were smashed or pushed into rooms by the force of the wind; the plaster in rooms was shattered. [ ... ] Trees disappeared from gardens. If roots resisted the strong wind, then tree-trunks were twisted off. [ . . . ] Cereal crops disappeared in the belt of the whirlwind, potatoes lost their tops; naked fields and ruins of farmsteads presented a miserable sight. Most of the hay and straw [blown] from gardens and barns was not found. [ ... ] On the opposite edge of the village [people] had no idea about the raging of the whirlwind ["smršt"']. A rotating whirl that raised dust was [all that seemed] to take place, so it appeared as if the village was shrouded in smoke. [... ]". Examples of damage that was done during this tornado appear in Figure 2.
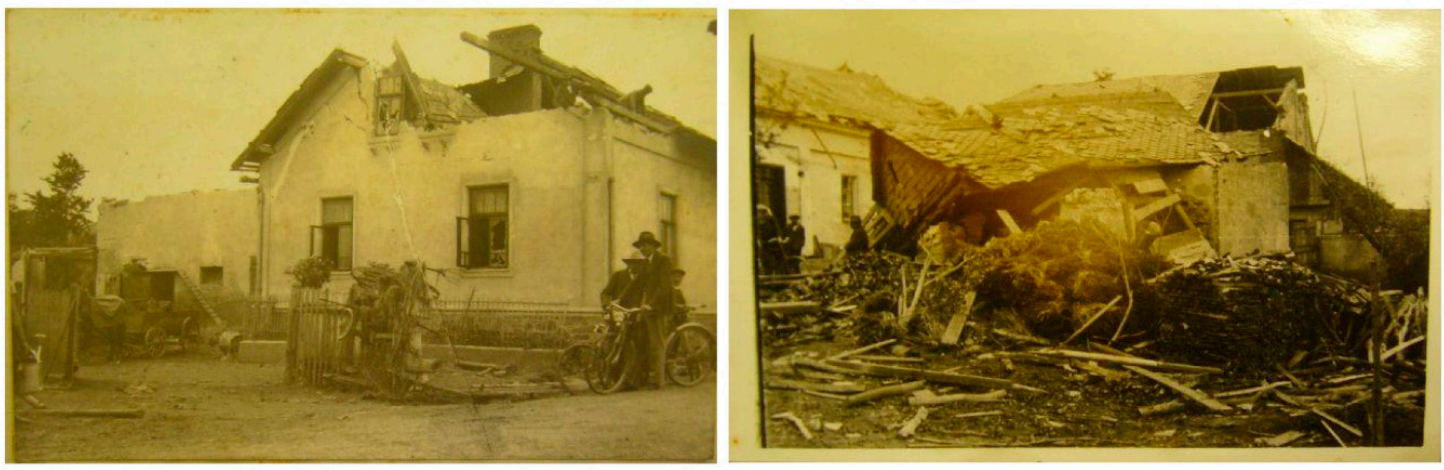

Figure 2. Buildings damaged during the F3 tornado in Milostovice on 21 June 1932 (source: [73]).

\subsection{Meteorological Data}

Dynamic-climatological analysis of significant tornadoes is based on circulation patterns, which are categorized into subjective classifications of daily synoptic types. The Hess-Brezowsky classification of synoptic types (Grosswetterlagen) [74] is of territorial focus, confined to central Europe and particularly to Germany. It started in 1881 and has been continuously extended up to the present $[75,76]$. Based on 
the position of the Azores High, it distinguishes 3 circulation types: zonal, mixed and meridional. These are further divided into 2 zonal, 3 mixed, and 13 meridional synoptic situations, further refined according to the cyclonic or anticyclonic character of the weather in central Europe (a total of 29 synoptic types).

A second classification of daily synoptic types was developed by the synoptic meteorologists of the CHMI [77]. It started in 1946 and has been systematically extended at a daily scale to the present [78]. This classification is generally based on the direction of airflow and the cyclonic/anticyclonic character of weather patterns, while the positions of pressure highs and lows are also taken into consideration. Until the year 1990, synoptic types were classified for the entire territory of what was then the geopolitical unit of Czechoslovakia; after 1991, the CHMI classification ran separately for the territories of the Czech Republic and the Slovak Republic. It defines a total of 28 main synoptic types (for more details, see [79]).

Tornadogenesis is a complex process. It requires the basics for deep, moist convection (instability, moisture, and lift [80]) in addition to other factors that may be investigated by looking into the larger-scale conditions, or "environment", surrounding the storm. Most strong tornadoes are associated with supercells [81], which require the presence of strong, vertical wind shear in the deep layer [82,83]. However, only very few supercells produce a tornado [84]. Field research and idealized numerical simulations have demonstrated that overly negative buoyant downdrafts and weak dynamically-induced accelerations through the lower section of the parent updraft preclude tornadogenesis $[85,86]$. Parameters that have shown success at representing the negative buoyancy of downdrafts and the potential of dynamically-induced vorticity extending to near the ground include measurement of the height of the cloud base (LCL) and of vertical wind shear near the ground [83,87-90]. Additionally, the degree of stream-wise vorticity (storm-relative helicity) near the ground has been found to be critical in discriminating significantly tornadic and non-tornadic supercells [91].

In this study, the environmental conditions associated with significant tornadoes over the Czech Republic were investigated in terms of the 5th generation of the European Centre for Medium-Range Weather Forecasts (ECMWF) atmospheric re-analysis (ERA-5; [92]) for the period of 1979-2018. ERA-5 provides meteorological variables at a horizontal grid spacing of $0.25^{\circ}$ and 137 terrain-following, hybrid-sigma model levels with a temporal resolution of $1 \mathrm{~h}$. The parameters used in the current study were calculated using vertically interpolated fields of temperature, humidity, pressure, geopotential, and $\mathrm{U}$ and $\mathrm{V}$ wind-vector components.

\subsection{Methods}

\subsubsection{Selection and Basic Analysis of Tornadoes}

There exists sufficient documentary data to classify tornadoes as "proven" and "probable". Contemporaneous accounts supply reports that may be comprehensive enough for "proven", with definite levels of intensity based on the Fujita scale $[66,67]$, or they may lack the detail required for this, thereby falling into the "probable" category. Only those achieving intensities of F2, F2-F3 and F3 were selected for further analysis (Table A1). To each such event was added the date of occurrence, time/part of the day, places affected, types of damage, numbers of deaths and injuries, and finally synoptic type according to Hess-Brezowsky [74] and CHMI [77] classifications. The types of damage were divided by character into 6 categories: A-buildings considerably damaged or ruined; $\mathrm{B}$ - minor damage to buildings; $\mathrm{C}$-damage to forests; $\mathrm{D}$ - uprooted and broken fruit trees and trees out of forest; E-damage to field crops and/or garden and orchard harvests; F-other damage (e.g., upturned carriages/vehicles, minor damage to property, downed or damaged telegraph and electricity poles, etc.).

Tornadoes that produced F2, F2-F3 and F3 damage were investigated further via annual and decadal numbers of tornadoes, their annual distribution, geographical distribution, distribution of 
damage types, numbers of deaths and injuries, and synoptic types of both classifications attributed to individual tornadoes.

\subsubsection{Environmental Conditions Associated with Tornadoes}

With respect to the time-span of the ERA- 5 re-analysis, significant tornadoes occurring before 1979 were not incorporated into the analysis, which left 27 cases (see Table A1). The parameters of environmental conditions associated with selected tornadoes investigated included: Convective Available Potential Energy (CAPE) calculated using the 0-500 m mixed-layer (MLCAPE) and the most-unstable parcels (MUCAPE); lifted condensation level for the mixed-layer parcel (LCL); bulk vertical wind shear in the 0-6 km (Shear6), 0-3 km (Shear3) and 0-1 km (Shear1) layers; and storm-relative helicity in the $0-3 \mathrm{~km}$ (SRH3) and 0-1 km layers (SRH1). Virtual temperature correction was applied for parcel calculation [93], and SRH values were calculated for a right-moving supercell storm motion vector using Bunkers' internal dynamics method [94]. Parameters were selected on the basis of their utilization in current tornado forecasting practice and/or appearance in the current literature (e.g., $[28,29,83,95,96])$. Parameters were calculated for the grid point closest to the tornado location and for the nearest whole hour to tornado occurrence time. No research has been published yet regarding the biases inherent to the ERA-5 model, but previous re-analyses have proved prone to biases in thermodynamic parameters, such as CAPE, and underestimation of Shear1 [97,98].

\section{Results}

\subsection{Spatiotemporal Variability}

A total of 108 significant tornadoes occurring over the territory of the Czech Republic, on 90 days (six tornadoes not exactly dated) and in 71 individual years, were documented. A complete list of them, with relevant basic information, appears in Table A1. The first reliable tornado report comes from Canon Kosmas from Prague, renowned author of "The Chronicle of the Czechs", who recorded damage to the prince's castle in Vyšehrad for 30 July 1119 [99]; this was classified as of F3 intensity. Reports of the subsequent five tornadoes reached as far as the last two decades of the 16th century: four in the 1580s occurred in Bohemia; the fifth, on 5 August 1592 in the town of Fulnek, was the first significant tornado documented in Moravia and Silesia [100]. After one recorded case in the 17th century, four more were documented in the 18th century. Four of the 11 tornadoes were classified at intensity F2, 2 at F2-F3, and 5 at F3. All of them occurred between May and August. Of 11 significant tornadoes, 9 took place in Bohemia, while only 2 were recorded in Moravia (after the Fulnek event, there was a tornado in Olomouc on 13 August 1701).

The period from the tornado of 2 June 1811, the first such case in the 19th century, until the most recent tornado occurrence on 23 September 2018 makes up the time for which the majority of significant tornadoes (total 97) were recorded and further statistically analyzed. Of this total, $72.2 \%$ were "proven" tornadoes and $27.8 \%$ "probable". While only 25 tornadoes were documented for the 19th century, the figure grew to 58 for the 20th century; 14 were recorded after 2000. Three significant tornadoes per day took place on both 5 July 1916 and 31 May 2001, while there were eight individual days upon which two significant tornadoes occurred in the interval between 1910 and 1990 (Table A1).

In terms of individual years, significant tornadoes were documented in 61 individual years of the 1811-2019 period, with the highest frequency, four events a year, occurring in 1928, 1932, 1935, and 2001 (Figure 3a); three tornadoes appeared within five years of one another and two within 14 years. At a scale of individual decades, the highest frequencies of significant tornadoes were apparent in 1931-1940 (15 events), 1921-1930 (12), and 2001-2010 (10). No tornado of such intensity was recorded for two separate decades, 1851-1860 and 1971-1980 (Figure 3b). 


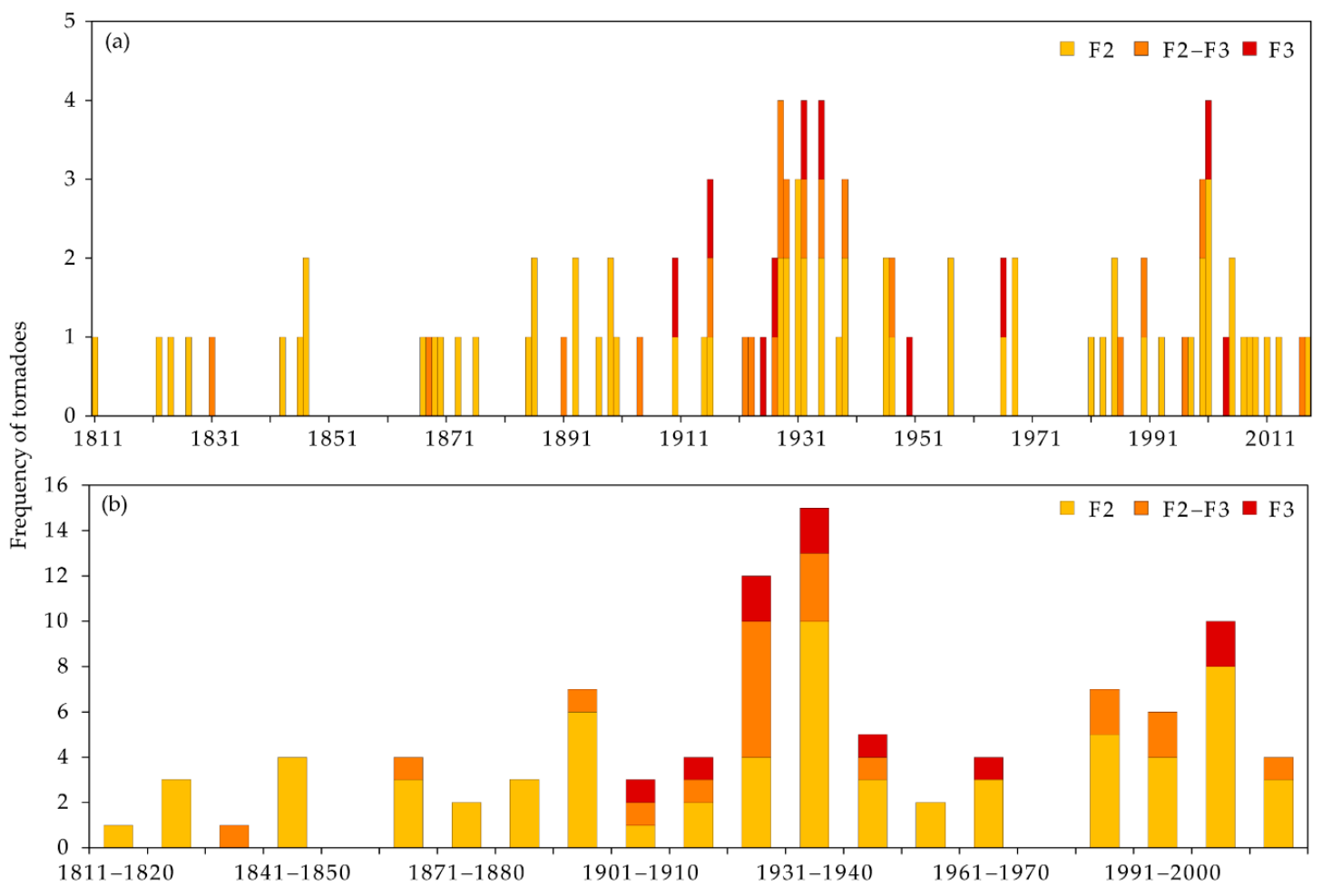

Figure 3. Annual (a) and decadal (b) frequencies of F2, F2-F3 and F3 tornadoes, classified by intensity, in the 1811-2019 period in the Czech Republic.

Turning to the annual variation in significant tornadoes during the 1811-2019 period (Figure 4), such events tended to occur in July (25.8\%) and June (22.7\%), followed by August (17.5\%) and May $(12.4 \%)$. The frequency of tornadoes in April was slightly higher than that in September. While most common during the months of the summer half-year (April-September), tornadoes have also occurred in October and January (4.1\% altogether), and the same proportion of tornadoes was inaccessible to exact dating. The order of months remains the same for frequencies of F2 tornadoes, with the proviso that the proportion of September events was higher than that of April. F2-F3 tornadoes occurred only from April to August, with their frequency at its highest in the latter month. F3 tornadoes were again documented in all months of the summer half-year, with a maximum in June.

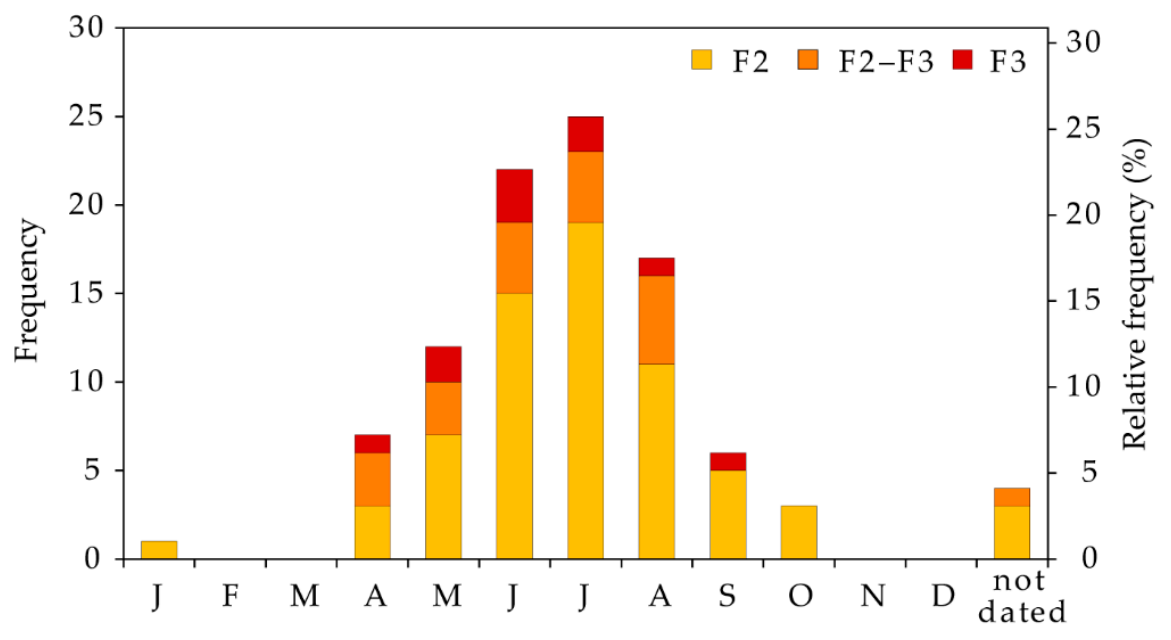

Figure 4. Annual variation of absolute and relative frequencies of F2, F2-F3 and F3 tornadoes in the Czech Republic in the 1811-2019 period (J, F, ... , D-months). 
Analysis of variations in significant tornado occurrence during a given day (Table A1) indicates that they have a strong tendency to take place in the afternoon and early evening hours. Although it was impossible to specify the exact time at which 19 tornadoes $(19.6 \%)$ took place, $12(12.4 \%)$ occurred in the 15-16 $\mathrm{h}$ Local Mean Time (LMT $=\mathrm{UTC}+\sim 1 \mathrm{~h}$ ) interval, $9(9.3 \%)$ between $16 \mathrm{~h}$ and $17 \mathrm{~h} \mathrm{LMT}$ and $8(8.2 \%)$ between $14 \mathrm{~h}$ and $15 \mathrm{~h}$ LMT-i.e., 29 tornadoes (29.9\%) between $14 \mathrm{~h}$ and $17 \mathrm{~h}$ LMT. Over $60 \%$ of all tornadoes (60, i.e., $61.9 \%)$ occurred between $12 \mathrm{~h}$ and $20 \mathrm{~h}$ LMT. In contrast, 14 tornadoes $(14.4 \%)$ were recorded for the evening and early night-time (20 h-01 h LMT) and only $4(4.1 \%)$ in the morning hours before noon.

The geographical distribution of significant tornadoes over the Czech Republic (Figure 5) features certain areas in which they have been completely absent and others in which quite a high concentration appears. A number of lines or belts of tornado occurrence are evident, arranged from the south-west to the north-east. Two lines/belts are clearly expressed in north-western and western Bohemia, which are matched or exceeded by a belt extending from the broader Brno area (No. 24 in Figure 5) in Moravia to the border with Poland. An additional two or three lesser lines may be further distinguished in Bohemia.

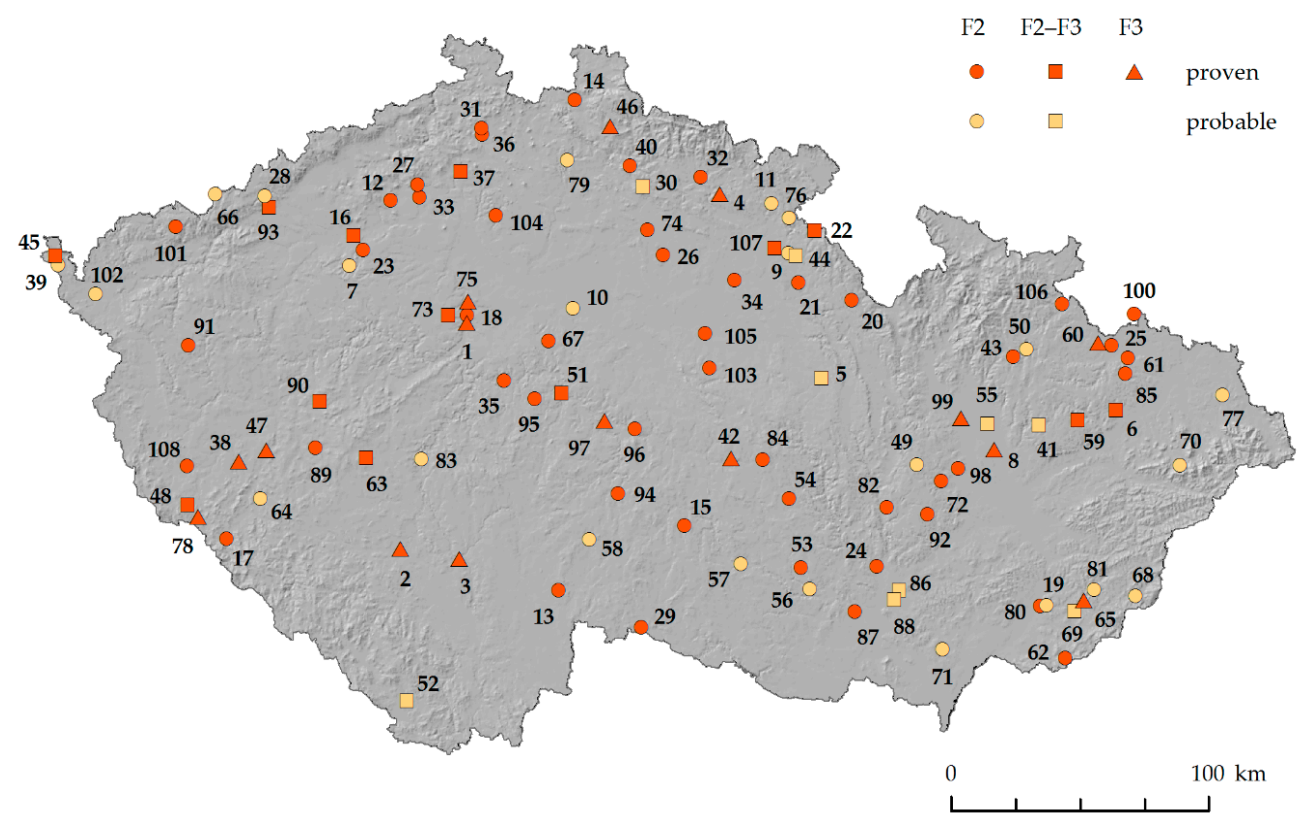

Figure 5. Geographical distribution of the occurrence of F2, F2-F3 and F3 tornadoes over the Czech Republic (numbers correspond to individual cases in Table A1; the first place in which the tornado occurred is always the one recorded). Places with tornado occurrence are classified according to whether the tornado was proven or probable, and corresponding intensity.

\subsection{Damage and Casualties}

Tornadoes are responsible for a wide range of material damage as well as casualties, including fatalities among people. Attributing particular types of damage to individual tornadoes, based on the six categories specified in Section 2.4.1, reveals (Figure 6) that nearly $90 \%$ of all significant tornadoes involved buildings heavily damaged or ruined by the event (A-88.7\%), while almost two-thirds of them were associated with damage to individual trees in gardens, those lining roads, in orchards, etc. (D-66.0\%). Nearly $50 \%$ of all tornadoes did damage to forestry timber $(C-49.5 \%)$, and a slightly lower proportion were responsible for other types of damage such as fallen telephone and electricity poles, upturned trailers and wagons, etc. ( $\mathrm{F}-46.4 \%)$. The two remaining types of damage (B, E) occurred in less than $10 \%$ of all tornadoes. 


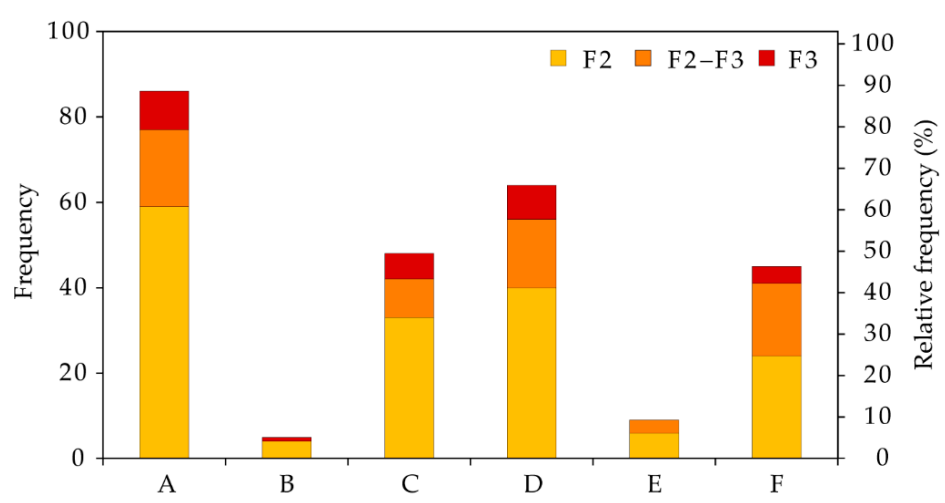

Figure 6. Absolute and relative frequencies of F2, F2-F3 and F3 tornadoes with the various classes of damage over the Czech Republic in the 1811-2019 period. For A-F, classification of damage, see Section 2.4.1.

Human casualties and fatalities during tornado events are always of particular note. People have been thrown to the ground by the force of the wind, even lifted into the air, carried some distance and dashed to earth, or injured or slain by flying matter, falling buildings, branches, or whole trees, etc. The database reports eight deaths (F2 five, F2-F3 two, F3 one) during six tornadoes, and more than 95 injuries (F2 33, F2-F3 34, F3 28) during 27 tornadoes. For example, on 1 October 1900 "The farmer Förster was lifted to a height by a storm and was carried aloft for $30 \mathrm{~m}$, after which he was thrown upon a barn which was falling into ruin; he was heavily injured." [101]. On the afternoon of 23 April 1904, a tornado overturned three wagons of a moving train on the track between Bližzevedly and Úštěk (northern Bohemia); nobody died, but 25 people were injured, 19 of them severely [50,102].

\subsection{Dynamic Climatology}

In order to demonstrate whether tornado occurrence is related to larger circulation patterns, daily synoptic types arranged into two types of classification were attributed to the significant tornadoes. The Hess-Brezowsky system of synoptic types [74] enabled the classification of 76 tornadoes from 1881 onwards (six other tornadoes were not exactly dated). In particular, zonal circulation of western cyclonic type (WZ) occurred in the cases of 24 tornadoes (31.6\%); together with the three other western types, this figure even reached 30 such events (39.5\%). This was followed by 26 tornadoes in the course of meridional circulation (34.2\%), for which the most important types involved a trough of low pressure over western Europe (TRW) for 8 tornadoes (10.5\%) and a trough over central Europe (TRM) for $7(9.2 \%)$. Mixed circulation types were associated with only 20 tornadoes $(26.3 \%)$, while north-western cyclonic type (NWZ) coincided with 6 (7.9\%), and south-western cyclonic type (SWZ) with $5(6.6 \%)$. Summarizing the proportions of tornadoes for only the five types WZ, TRW, TRM, NWZ and SWZ, these accounted for almost two-thirds $(65.8 \%)$ of them. Apart from this, tornadoes occurred in association with 11 other types, while 13 types within the Hess-Brezowsky classification remained without tornado occurrence.

The second classification, that of the CHMI [77], covers only 36 tornadoes from 1946 onwards (two cases not dated). Of 13 synoptic types during which tornadoes occurred, the trough of low pressure over central Europe (B) proved the most important (seven events, i.e., 19.4\%), which, together with a trough advancing over central Europe (Bp), achieved 11 cases (30.6\%). The western cyclonic type (Wc) coincided with five tornadoes (13.9\%) and, together with other western types, totaled nine events $(25.0 \%)$. In addition, comparable is the proportion of the three south-west cyclonic types $\mathrm{SWc}_{1-3}$ (eight tornadoes, i.e., 22.2\%). These results exhibit a general consistency with the Hess-Brezowsky classification. 


\subsection{Environmental Conditions}

Significant tornadoes over the territory of the Czech Republic originated in a wide variety of environments from the perspective of the parameters studied herein (Table 1). High CAPE values are not required for tornado occurrence, and half the cases were associated with MLCAPE and MUCAPE values under $500 \mathrm{~J} \mathrm{~kg}^{-1}$ and $900 \mathrm{~J} \mathrm{~kg}^{-1}$, respectively. The median value of Shear6 was $20.8 \mathrm{~m} \mathrm{~s}^{-1}$, which suggests that many of the strong tornadoes over the Czech Republic were associated with well-organized super-cellular convection. There were, however, exceptions. For example, the 19 April 2000 case involved only $13 \mathrm{~m} \mathrm{~s}^{-1}$ of Shear6 and $2 \mathrm{~m} \mathrm{~s}^{-1}$ of Shear1, probably rendering the tornado of non-mesocyclonic origin. Non-mesocyclonic tornadoes, in comparison with those of mesocyclonic origin, may also occur within a regime of weak vertical wind shear [103].

Table 1. Distribution of values associated with selected parameters expressed by utilizing percentiles and standard deviation (st. dev.) for 27 significant tornadoes over the Czech Republic in the 1979-2019 period.

\begin{tabular}{ccccccccc}
\hline Percentile & $\begin{array}{c}\text { MLCAPE } \\
\left(\mathbf{J ~ k g}^{-\mathbf{1}}\right)\end{array}$ & $\begin{array}{c}\text { MUCAPE } \\
\left(\mathbf{J ~ k g}^{-1}\right)\end{array}$ & $\begin{array}{c}\text { Shear6 } \\
\left(\mathbf{m ~ s}^{-1}\right)\end{array}$ & $\begin{array}{c}\text { Shear3 } \\
\left(\mathbf{m ~ s}^{-1}\right)\end{array}$ & $\begin{array}{c}\text { Shear1 } \\
\left(\mathbf{m ~ s}^{-1}\right)\end{array}$ & $\begin{array}{c}\text { SRH3 } \\
\left(\mathbf{m}^{\mathbf{2}} \mathbf{~ s}^{-\mathbf{2}}\right)\end{array}$ & $\begin{array}{c}\text { SRH1 } \\
\left(\mathbf{m}^{\mathbf{2}} \mathbf{~ s}^{-\mathbf{2}}\right)\end{array}$ & $\begin{array}{c}\text { LCL } \\
(\mathbf{m})\end{array}$ \\
\hline 10 & 69.3 & 144.7 & 13.0 & 8.3 & 2.3 & 31.6 & 10.3 & 490.0 \\
25 & 169.4 & 405.7 & 16.2 & 10.5 & 4.5 & 86.0 & 24.4 & 837.5 \\
50 & 512.4 & 793.5 & 20.8 & 12.9 & 6.8 & 117.2 & 61.8 & 949.0 \\
75 & 886.0 & 1214.9 & 29.3 & 19.9 & 9.5 & 189.0 & 107.7 & 1130.5 \\
90 & 1192.9 & 1618.0 & 36.2 & 30.5 & 13.1 & 286.7 & 175.8 & 1630.0 \\
st. dev. & 483.8 & 667.6 & 12.2 & 8.4 & 6.0 & 112.7 & 87.0 & 522.1 \\
\hline
\end{tabular}

A large number of the parameters studied exhibit marked temporal variability (Table 2). The largest variability is noted for both MLCAPE and MUCAPE, as well as for the measures of shear in the lowest $1 \mathrm{~km}$ (Shear1 and SRH1). While the median change between one hour before the tornado and the tornado hour itself (or one hour before and one hour after the tornado) is quite small, the values for standard deviation are high, suggesting that considerable shifts are possible in either direction. In the case of shear-related parameters, there is no clear tendency towards either increase or decrease in values before and after tornado occurrence. For MLCAPE, MUCAPE, and LCL, there are more cases in which the values decreased approaching the time of tornado and after tornado occurrence. This probably reflects either cooling and moistening of the boundary layer in the late afternoon hours or the effects of simulated storms within the model. In the cases of CAPE, SRH3, and SRH1 the standard deviation in change is very similar or even exceeds the standard deviation of the values at the tornado hour. The temporal variability of values of these parameters exceeds the spatial variability (not shown). As a result of the high spatial and temporal variability of some of the parameters, especially SRH [104], precise determination of tornado occurrence time and location appear to be crucial to the correct identification of the conditions leading up to the tornadoes investigated.

Table 2. Median, standard deviation (st. dev) and the number of the cases with a positive and negative change in the values of selected parameters between the tornado hour and one hour before the tornado (T0-T-1), as well as between one hour after the tornado and one hour before the tornado (T+1-T-1) for 27 significant tornadoes over the Czech Republic in the 1979-2019 period.

\begin{tabular}{|c|c|c|c|c|c|c|c|c|}
\hline Characteristic & $\begin{array}{l}\text { MLCAPE } \\
\left(\mathrm{J} \mathrm{kg}^{-1}\right)\end{array}$ & $\begin{array}{l}\text { MUCAPE } \\
\left(\mathrm{J} \mathrm{kg}^{-1}\right)\end{array}$ & $\begin{array}{l}\text { Shear6 } \\
\left(\mathrm{m} \mathrm{s}^{-1}\right)\end{array}$ & $\begin{array}{l}\text { Shear3 } \\
\left(\mathrm{m} \mathrm{s}^{-1}\right)\end{array}$ & $\begin{array}{l}\text { Shear1 } \\
\left(\mathrm{m} \mathrm{s}^{-1}\right)\end{array}$ & $\begin{array}{c}\text { SRH3 } \\
\left(\mathrm{m}^{2} \mathrm{~s}^{-2}\right)\end{array}$ & $\begin{array}{c}\text { SRH1 } \\
\left(\mathrm{m}^{2} \mathrm{~s}^{-2}\right)\end{array}$ & $\begin{array}{l}\text { LCL } \\
(\mathrm{m})\end{array}$ \\
\hline \multicolumn{9}{|c|}{ T0-T-1 } \\
\hline median & -40.3 & 24.5 & -0.5 & -0.2 & -0.3 & -0.5 & 0.8 & -50.0 \\
\hline st. dev. & 302.0 & 323.3 & 2.3 & 2.5 & 1.6 & 71.3 & 40.5 & 248.0 \\
\hline positive & 11 & 15 & 11 & 12 & 10 & 13 & 14 & 11 \\
\hline negative & 16 & 12 & 16 & 15 & 16 & 14 & 13 & 16 \\
\hline \multicolumn{9}{|c|}{$\mathrm{T}+1-\mathrm{T}-1$} \\
\hline median & -83.3 & -54.3 & -1.1 & 0.8 & -0.2 & -6.1 & -7.2 & -175.0 \\
\hline st. dev. & 543.9 & 630.2 & 4.1 & 3.7 & 3.2 & 120.5 & 74.4 & 393.1 \\
\hline positive & 10 & 10 & 9 & 16 & 13 & 12 & 11 & 8 \\
\hline negative & 17 & 17 & 18 & 11 & 14 & 15 & 16 & 19 \\
\hline
\end{tabular}




\section{Discussion}

\subsection{Data Uncertainty}

The information and results presented herein for the analyses of significant tornadoes from the Czech Republic are biased by a range of uncertainties related to the mode of use and the intrinsic features of documentary evidence. Although some archives (particularly newspapers) may provide highly valuable data sources for tornado extraction, certain limits to this evidence cannot be ignored. For example, a database derived from the press is quite likely to suffer from spatiotemporal non-homogeneity. The number of available documentary sources generally increases from the past to the present and is also profoundly affected by general accessibility. This lies in close relationship to the temporal and spatial working opportunities available to researchers seeking tornado data. A further uncertainty follows from the actual quality of records and their interpretation. More detailed descriptions of events provide better opportunities for interpretation, including delimitation of event intensity based on recorded damage (see examples in Section 2.2), than those confined to brief records [64,65]. Moreover, the period of 209 years investigated may also be partly biased in the evaluation of the damage described, particularly to buildings, since approaches to architecture and construction have changed profoundly over the years. A further uncertainty may be related to the fact that the Fujita scale $[66,67]$ was developed on the basis of damage surveys in the U.S., where building practices and structures differ in some respects from those in the Czech Republic.

It should always be borne in mind that not all tornadoes were noticed and/or reported consecutively (e.g., those of weaker intensity, occurring in remote areas, and beyond the boundaries-or even the view-of villages and towns). Further, some records may have been lost over the course of time or have yet to be discovered by ongoing research. All of this means that we are working with numbers of tornadoes probably underestimated with respect to actual events.

Despite the uncertainties above, to the best of our knowledge, the database thus far established by derivation from documentary data is the most complete existing source of information for the study of tornadoes as severe, small-scale weather phenomena in the Czech Republic. Moreover, the continuation of the search for documentary sources definitely offers the possibility of revealing new information and further extension of the existing tornado database.

\subsection{The Broader Context}

This contribution focuses on category F2, F2-F3, and F3 tornadoes since they are the strongest to be noted and interpreted for the Czech Republic. Even though the interpretation of tornado intensity according to the Fujita scale is somewhat subjective, based on the damage done, it has been shown that still stronger (violent) tornadoes (F4-F5) may occur-quite exceptionally (0.8\%)—in Europe [48]. Tornadoes of category F4 have appeared in only 10 out of 23 European countries, while F5 tornadoes have been recorded only in Germany and France.

The first chronologies of Czech tornadoes, by Munzar [53,54] and Setvák et al. [58], were significantly extended by further publications based on systematic historical-climatological research. Among the most important of these is a paper by Brázdil et al. [61], which reported 307 tornadoes for the 1119-2010 period: 53 of these were attributed to intensity F2 (17.3\%), 15 to F2-F3 (4.9\%) and 11 to F3 (3.6\%), i.e., 79 significant tornadoes altogether (25.7\%). In a subsequent paper, Brázdil et al. [62] found a total of 367 tornadoes for the 1801-2017 period, of which 67 were of F2 intensity (18.3\%), 17 of F2-F3 (4.6\%) and 7 of F3 $(1.9 \%)$, i.e., 91 significant tornadoes altogether (24.8\%). It follows from these two papers that significant tornadoes constitute nearly a quarter of all such events recorded for the Czech Republic. The current contribution provides an extension of the existing chronology by a further 6 cases in the 1811-2019 period, to a total of 97 significant tornadoes: 67 F2, 20 F2-F3 and 10 F3. Comparing this with the newly-achieved number of 391 tornadoes for the 1811-2019 period (not shown), the proportions are: F2 17.1\%, F2-F3 5.1\%, and F3 2.6\%, a total of 24.8\%. This tallies well with Antonescu et al. [48], who reported in their European overview proportions of $24.5 \%$ for F2 and F3 tornadoes within their total number. The new 209-year-long 
Czech significant tornado chronology provides an average of only 0.46 tornadoes per year. If only the years in which at least one significant tornado occurred (61) are considered, then this becomes 1.59 tornadoes per year.

It must, however, be reiterated that working with the above figures must always allow for the weaknesses in documentary data, as outlined in Section 4.1. In the frequency of tornadoes detected (see e.g., Figure 3) the effects of "social bias" in documentary data may appear. Generally, in periods of crisis (wars, epidemics, political tension, natural disasters, etc.), attention turns away from "marginal" events in public space. For example, during the years of the Second World War (1939-1945), and in the early stages of the communist administration in what was then Czechoslovakia (1948-early 1960s), when newspapers concerned themselves almost exclusively with ideological matters and "building socialism", attention to damaging local/regional weather events was desultory, at best. The situation reversed in the late 1990s and the early 2000s, when "tornado" became a word highly attractive to the essentially sensationalist parts of the media (see 2001-2010 decade in Figure 2b). Other maxima of significant tornadoes, between 1921 and 1940, may result partly from expanded reporting on the part of a growing number of newspapers, when several of them even published three issues daily (morning, noon and evening). At this time, newspapers also turned far more of their attention towards the territory of newly-founded Czechoslovakia than they had before 1918, when the Czech Lands were part of the Austro-Hungarian Empire. The Czech significant tornado chronology corresponds, in general terms, with the findings of Antonescu et al. [48] for Europe; they reported a dramatic increase in all tornadoes detected: from 8 tornadoes a year in 1800-1850 to 242 tornadoes a year between 2000 and 2014.

The geographical distribution of significant tornadoes over the Czech Republic concentrates clearly into certain lines or belts extending from the south-west to the north-east (see Figure 5). They may bring to mind the "tornado alleys" so infamous in the USA [105]. Although some coincidence with similar belts of cumulonimbus clouds and thunderstorm cells during certain synoptic situations may be observed, it is difficult to estimate the extent to which this arises out of real meteorological conditions and the character of the orography, which may enhance convection (significant tornadoes tend to occur in the highlands and in river valleys), or whether the association is an artifact intrinsic to the extraction and interpretation of available documentary data. However, the effects of terrain on tornadoes are still poorly understood [106].

While Brázdil et al. [61] reported 13 tornado fatalities and Brázdil et al. [62] noted 17 fatalities, only 8 deaths in the course of 6 tornadoes are recorded for significant tornadoes in the current paper. This means that deadly tornadoes make up only $6.2 \%$ of their total, with a mean of 0.08 fatalities per tornado. These values are far lower than those in other countries. For example, Taszarek and Gromadzki [107], analyzing deadly tornadoes in Poland occurring between 1820 and 2015, disclosed an average of 1-2 killer tornadoes, with five fatalities per decade, but with a decreasing trend over time. In the "significant tornado" category, 5-10\% have led to fatalities, with a mean of 0.27 fatalities per tornado. An analysis of European tornadoes performed by Groenemeijer and Kühne [12], based on the European Severe Weather Database (ESWD), reported 0.28 fatalities per F3 tornado (2000-2013). F2 and F3 tornadoes were responsible for the majority of European fatalities (the mean annual number is estimated at between 10 and 15).

The occurrence of significant Czech tornadoes in the course of synoptic types that involve airflow from the western quadrant and troughs over central Europe (see Section 3.3) may be compared with the results of Bissoli et al. [44] in their investigation of tornadoes in Germany during the 1950-2003 period. Using the objective classification of weather types of the German Meteorological Service (DWD), they identified three specific weather types to which majority of German tornadoes may be attributed. All three were characterized by south-westerly advection and high humidity. 


\subsection{Environmental Conditions}

The distribution of the values of individual significant tornado parameters in the Czech Republic (Table 1) is similar to those reported by Púčik et al. [28] and Taszarek et al. [29] using sounding measurements over central Europe. Kaltenböck et al. [27] employed ECMWF analyses to investigate severe convective storms in Europe. For strong tornadoes, they found similar distributions of CAPE, but lower values for shear-related parameters. For example, the median SRH3 was $58 \mathrm{~m}^{2} \mathrm{~s}^{-2}$ compared with the $117 \mathrm{~m}^{2} \mathrm{~s}^{-2}$ found in the current study. Such large differences may be attributable to the longer, 6-hourly, temporal steps of their model data. Groenemeijer and van Delden [25] found lower CAPE, but more powerful vertical wind shear in association with strong (F2) tornadoes in The Netherlands.

Compared to the intense tornado environments over the U.S., Czech equivalents are associated with lower values of both CAPE and vertical wind shear, particularly with reference to the helicity in the lower troposphere ([83,87]). The median SRH1 is three times lower (62 vs. $165 \mathrm{~m}^{2} \mathrm{~s}^{-2}$ ) in the Czech Republic compared with the results of Thompson et al. [83] for the U.S. The CAPE values cannot be directly compared. The U.S. studies used the mixed layer of $1000 \mathrm{~m}$ or $100 \mathrm{hPa}$, compared with $500 \mathrm{~m}$ in this work. However, the finding of lower values is rendered still more substantial, given the expectation of larger MLCAPE values when calculated with the shallower mixed layer. While differences are of a lower order for the bulk shear measures, climatological studies have shown that the U.S. experiences an overlap of high CAPE and strongly-sheared environments more often than Europe [26,108]. This has a profound influence on the distribution of values associated with severe convective storms and brings into question the automatic application of the threshold values, or composite indices, developed in and for the U.S. (such as the Significant Tornado Parameter in Thompson et al. [83]) over other forecast domains. For example, $75 \%$ of Czech significant tornadoes were associated with Shear1 values of below $10 \mathrm{~m} \mathrm{~s}^{-1}$, a threshold value used for forecasting tornadoes based on the findings of Thompson et al. [83] and Craven and Brooks [89]. Further work to establish the climatological distributions of parameters such as CAPE and SRH1 associated with significant tornadoes is required for the Czech Republic; the threshold values of the composite indices originally developed for the U.S. need to be tuned. In central Europe, such parameter distributions have already been investigated by Púčik et al. [28] and Taszarek et al. [29] but their results were limited by very low sample numbers of significant tornadoes, collected over relatively short periods of time.

\section{Conclusions}

This paper analyses various aspects of significant tornado climatology over the Czech Republic. The main conclusions may be summarized as follows:

(i) A total of 108 proven and probable significant tornadoes, taking place on 90 days, was established from documentary evidence for the Czech Republic for the 1119-2019 period (97 tornadoes from 1811 CE onwards). The tornadoes identified occurred most frequently in the 1921-1930, 1931-1940, and 2001-2010 decades.

(ii) In terms of annual variation, July tornadoes clearly prevailed, followed by June and August. In addition to the months of the summer half-year, tornadoes also occurred in October and January. In the course of the day, tornadoes occurred particularly in the afternoon and early evening hours.

(iii) Lower estimates of deaths arising out of tornado events stand at 8 deaths and at least 95 injuries associated with significant tornadoes. The most frequent type of material damage was related to ruined buildings and the loss of individual trees and forestry timber.

(iv) Significant tornadoes tended to occur, according to the two classifications, in synoptic types characterized by airflow from the western quadrant together with various troughs extending over, or advancing through, central Europe.

(v) The environmental conditions associated with significant tornadoes, analyzed using the ERA-5 re-analysis, were characterized by a wide range of CAPE and vertical wind-shear 
magnitudes, lower than the magnitudes typically associated with strong tornadoes over the U.S. CAPE measurements and the parameters describing vertical wind shear in the lowest $1 \mathrm{~km}$ of the atmosphere exhibited pronounced temporal and spatial variability.

Author Contributions: Conceptualization, R.B.; methodology, R.B., K.C., T.P. and M.T.; formal analysis, R.B. and K.C.; data curation, Z.Č., P.D., L.D., O.K. and L.̌̌.; writing-review and editing, R.B. and T.P. All authors have read and agreed to the published version of the manuscript.

Funding: This research was funded by the Ministry of Education, Youth, and Sports of the Czech Republic for the SustES-Adaptation strategies for sustainable ecosystem services and food security under adverse environmental conditions project, ref. CZ.02.1.01/0.0/0.0/16_019/0000797.

Acknowledgments: We would like to thank Tony Long (Svinošice) who helped work on the English.

Conflicts of Interest: The authors declare no conflict of interest.

\section{Appendix A}

Table A1. List of documented significant tornadoes for the Czech Republic and their basic characteristics. Key: type: 1-proven tornado, 2-probable tornado; type of damage A-F, see Section 2.4.1 for categorization; synoptic type according to Hess-Brezowsky classification [74] appears on the left and CHMI classification [77] on the right.

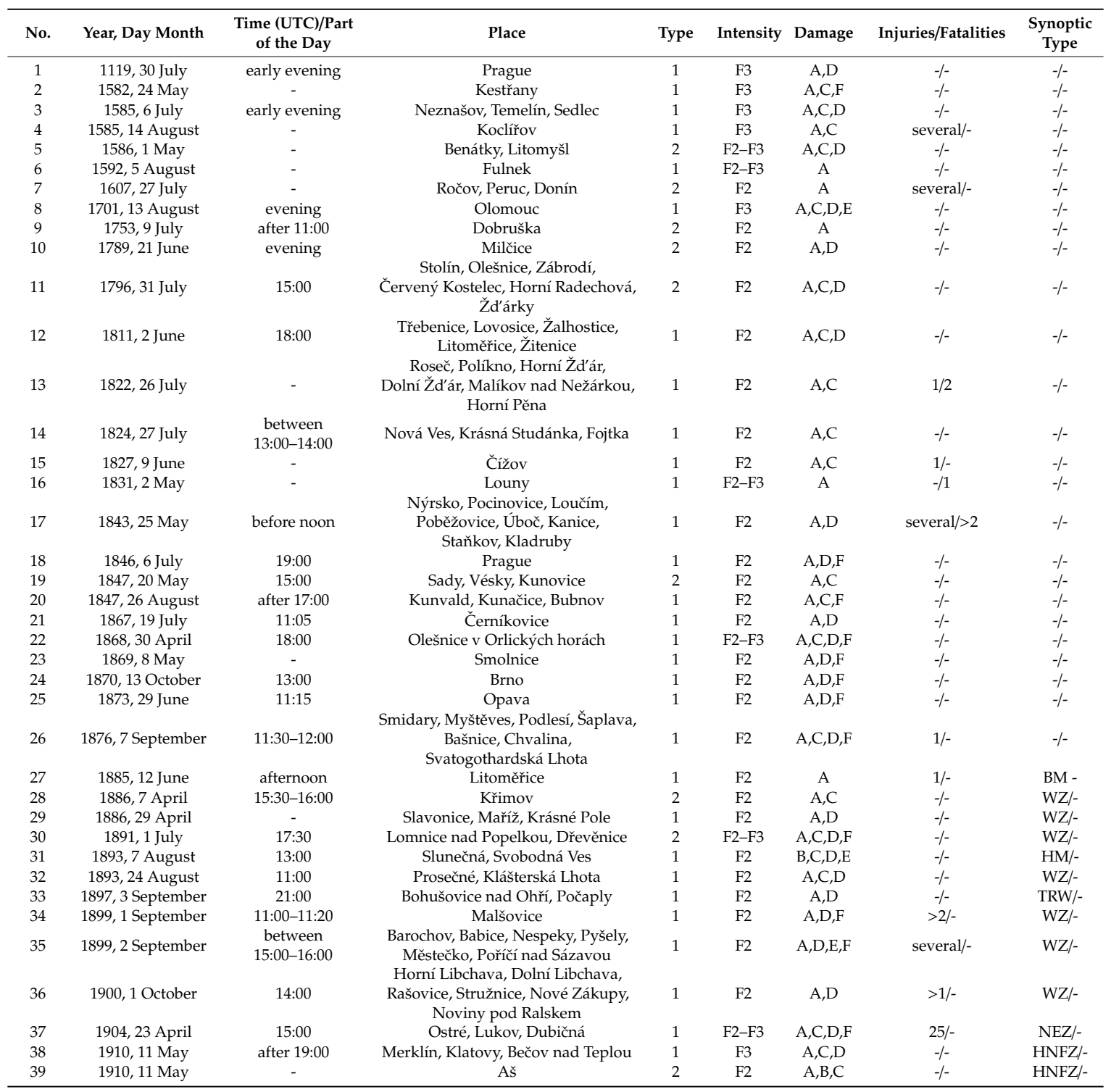


Table A1. Cont.

\begin{tabular}{|c|c|c|c|c|c|c|c|c|}
\hline No. & Year, Day Month & $\begin{array}{l}\text { Time (UTC)/Part } \\
\text { of the Day }\end{array}$ & Place & Type & Intensity & Damage & Injuries/Fatalities & $\begin{array}{l}\text { Synoptic } \\
\text { Type }\end{array}$ \\
\hline 41 & 1916, 5 July & 14:30 & Velká Střelná & 2 & F2-F3 & $\mathrm{A}, \mathrm{C}, \mathrm{D}$ & $-1-$ & TRM/- \\
\hline 43 & 1916, 5 July & - & Břidličná & 1 & F2 & $\mathrm{A}, \mathrm{C}$ & $-1-$ & TRM/- \\
\hline 44 & 1922, 16 August & after 19:30 & Dobruška & 2 & F2-F3 & $\mathrm{A}, \mathrm{C}, \mathrm{D}, \mathrm{F}$ & $-1-$ & WW/- \\
\hline 45 & 1923, 9 May & $17: 00$ & Krásná, Aš & 1 & $\mathrm{~F} 2-\mathrm{F} 3$ & $\mathrm{~A}, \mathrm{D}, \mathrm{F}$ & $3 /-$ & $\mathrm{NZ} /-$ \\
\hline 46 & 1925,11 August & before 23:00 & $\begin{array}{l}\text { Jablonecké Paseky, Proseč nad Nisou } \\
\text { Snopoušov, Horní Lukavice, }\end{array}$ & 1 & F3 & $\mathrm{A}, \mathrm{C}, \mathrm{D}, \mathrm{F}$ & $2 /-$ & $\mathrm{HM} /-$ \\
\hline 48 & 1927, 4 June & $12: 30$ & Tlumačov & 1 & F2-F3 & $\mathrm{A}, \mathrm{D}, \mathrm{F}$ & $-1-$ & NWZ/- \\
\hline 49 & 1928 , before 3 July & - & Brodek u Konice & 2 & $\mathrm{~F} 2$ & $\mathrm{~A}, \mathrm{C}$ & $-1-$ & $-/$ \\
\hline 50 & 1928, 4 July & - & $\begin{array}{l}\text { Valšov, Harrachov, Edrovice, } \\
\text { Janovice, Janušov, } \\
\text { Jamartice, Rýmařov }\end{array}$ & 2 & $\mathrm{~F} 2$ & $\mathrm{~A}, \mathrm{~F}$ & 3/- & WZ/- \\
\hline 51 & 1928, 1 August & 15:00 & Český Šternberk, Drahňovice & 1 & F2-F3 & $\mathrm{A}, \mathrm{C}, \mathrm{D}, \mathrm{E}, \mathrm{F}$ & $-1-$ & NWA/- \\
\hline 55 & 1929,25 July & - & Štěpánov, Hlušovice & 2 & F2-F3 & F & $-1-$ & NWA/- \\
\hline 56 & 1931, 10 June & $16: 00$ & $\begin{array}{l}\text { Senorady, Lhánice, Mohelno, } \\
\text { Kladeruby nad Oslavou }\end{array}$ & 2 & $\mathrm{~F} 2$ & $\mathrm{~A}, \mathrm{C}, \mathrm{D}$ & - & WZ/- \\
\hline 57 & 1931, 18 June & $14: 30$ & Třebíč & 2 & F2 & $\mathrm{A}, \mathrm{F}$ & $>4 /-$ & WZ/- \\
\hline 58 & 1931, June & - & Kamenice nad Lipou & 2 & F2 & C & $-1-$ & $-/$ \\
\hline 59 & 1932,21 June & $16: 30$ & Luboměř, Spálov, Lipná & 1 & F2-F3 & $\mathrm{A}, \mathrm{C}, \mathrm{D}, \mathrm{F}$ & $5 /-$ & HNZ/- \\
\hline 60 & 1932, 21 June & 17:00 & Milostovice, Držkovice & 1 & F3 & $\mathrm{A}, \mathrm{D}, \mathrm{E}, \mathrm{F}$ & $17 /-$ & $\mathrm{HNZ} /-$ \\
\hline 61 & 1932, 3 August & 14:00 & Suché Lazce & 1 & F2 & $\mathrm{A}, \mathrm{D}, \mathrm{E}, \mathrm{F}$ & $1 /-$ & WA/- \\
\hline 62 & 1932, 7 August & $14: 30$ & Nová Lhota & 1 & F2 & A,D & $-1-$ & NWA/- \\
\hline 63 & 1935, 8 April & 15:00 & Bezděkov pod Třemšínem & 1 & F2-F3 & $\mathrm{A}, \mathrm{C}$ & $1 / 1$ & WZ/- \\
\hline 64 & 1935, 15 June & evening & Točník & 2 & F2 & $\mathrm{A}, \mathrm{D}$ & $-/-$ & $\mathrm{WZ} /-$ \\
\hline 65 & 1935,6 September & $17: 00$ & Polichno & 1 & F3 & $\mathrm{A}, \mathrm{D}, \mathrm{F}$ & several/1 & $\mathrm{WZ} /-$ \\
\hline 66 & 1935, before 3 July & - & $\begin{array}{l}\text { Vejprty, Přísečnice, } \\
\text { Kryštofovy Hamry }\end{array}$ & 2 & $\mathrm{~F} 2$ & $\mathrm{~A}, \mathrm{C}$ & $-1-$ & $-/-$ \\
\hline 75 & 1950, 20 April & $15: 20-15: 30$ & $\begin{array}{l}\text { Bašt', Bohnice, Čimice, Dolní Chabry, } \\
\text { Kojetice, Sedlec, Zdiby }\end{array}$ & 1 & F3 & $\mathrm{A}, \mathrm{D}$ & $-1-$ & NEZ/B \\
\hline 76 & 1957, 14 August & - & $\begin{array}{c}\text { Náchod } \\
\text { Těrlicko, Životice, Albrechtice, }\end{array}$ & 2 & $\mathrm{~F} 2$ & $\mathrm{D}$ & $-1-$ & $\mathrm{TRW} \mathrm{SWC}_{3}$ \\
\hline 77 & 1957, 14 August & evening & $\begin{array}{l}\text { Louky, Chotěbuz, Stonava, } \\
\text { Třanovice, Tošanovice }\end{array}$ & 2 & $\mathrm{~F} 2$ & $\mathrm{~A}, \mathrm{C}$ & $-1-$ & $\mathrm{TRW} / \mathrm{SWc}_{3}$ \\
\hline 78 & 1966, 18 July & 16:00 & $\begin{array}{l}\text { Bělohrad, Studánky, Hájek, Hyršov, } \\
\text { Pláně, Sruby }\end{array}$ & 1 & F3 & $\mathrm{A}, \mathrm{C}$ & 8/- & $\mathrm{NEZ/Ec}$ \\
\hline 79 & 1966, July & - & Vrtky & 2 & F2 & $\mathrm{B}, \mathrm{C}, \mathrm{D}, \mathrm{F}$ & $-1-$ & $-/-$ \\
\hline 80 & 1968,11 July & 13:00 & Kunovice & 1 & $\mathrm{~F} 2$ & A,D & $-/ 1$ & $\mathrm{NWZ/SWc_{2 }}$ \\
\hline 81 & 1968,11 July & afternoon & Luhačovice & 2 & F2 & $\mathrm{C}$ & $7 /-$ & $\mathrm{NWZ} / \mathrm{SWc}_{2}$ \\
\hline 82 & 1981, 11 October & 12:00 & Karolín, Rájec-Jestřebí & 1 & F2 & A & $-1-$ & $\mathrm{WZ} / \mathrm{Wcs}$ \\
\hline 83 & 1983,1 August & early evening & Trhovky, Kosobudy & 2 & $\mathrm{~F} 2$ & $\mathrm{~A}, \mathrm{D}, \mathrm{F}$ & $-1-$ & NEZ/B \\
\hline 84 & 1985,10 June & $17: 15$ & Lhotka & 1 & F2 & $\mathrm{A}, \mathrm{D}$ & $-1-$ & TRM/Wc \\
\hline 85 & 1985, 21 July & 13:40 & Hlubočec & 1 & F2 & $\mathrm{A}, \mathrm{C}, \mathrm{D}, \mathrm{F}$ & $-1-$ & $\mathrm{WZ} / \mathrm{Wc}$ \\
\hline 86 & 1986, 19 August & evening & Sokolnice & 2 & $\mathrm{~F} 2-\mathrm{F} 3$ & $\mathrm{~A}, \mathrm{D}, \mathrm{F}$ & $-1-$ & $\mathrm{SWZ} \mathrm{SWc}_{3}$ \\
\hline 87 & 1990, 24 May & evening & Kupařovice & 1 & F2 & A & $-1-$ & $\mathrm{HB} / \mathrm{B}$ \\
\hline 88 & 1990, 24 May & evening & Měnín & 2 & F2-F3 & F & $-1-$ & $\mathrm{HB} / \mathrm{B}$ \\
\hline 89 & 1993, 16 July & 18:15-18:30 & Spálené Poříčí & 1 & F2 & $\mathrm{A}, \mathrm{C}, \mathrm{D}, \mathrm{F}$ & $-1-$ & WZ/Wc \\
\hline 90 & 1997,27 June & $23: 10$ & Díly, Volduchy & 1 & $\mathrm{~F} 2-\mathrm{F} 3$ & A,D & $-1-$ & $\mathrm{TRW}^{\mathrm{SWW}} \mathrm{c}_{1}$ \\
\hline 91 & 1998, 21 July & $22: 00$ & $\begin{array}{l}\text { Heřmanov, Ovčí Dvůr, } \\
\text { Pěkovice, Prachomety }\end{array}$ & 1 & $\mathrm{~F} 2$ & $\mathrm{~A}, \mathrm{C}$ & $-/-$ & $\mathrm{SWZ} / \mathrm{SWc}_{1}$ \\
\hline 92 & 2000, 19 April & $15: 15-15: 30$ & Studnice & 1 & F2 & $\mathrm{A}, \mathrm{D}$ & $-1-$ & SWZ/Ec \\
\hline 93 & 2000, 11 June & $16: 00$ & Málkov & 1 & F2-F3 & $\mathrm{A}, \mathrm{C}, \mathrm{D}, \mathrm{E}, \mathrm{F}$ & $-1-$ & $\mathrm{BM} / \mathrm{Bp}$ \\
\hline 94 & 2000, 2 July & 14:00 & Krasíkovice & 1 & F2 & $\mathrm{A}, \mathrm{C}, \mathrm{F}$ & $-1-$ & $\mathrm{SWZ} / \mathrm{SWc}_{3}$ \\
\hline 95 & 2001, 31 May & 14:00 & Kochánov, Střížkov & 1 & $\mathrm{~F} 2$ & $\mathrm{D}$ & $-1-$ & $\mathrm{WA} / \mathrm{Vfz}$ \\
\hline 96 & 2001, 31 May & $15: 00$ & Vilémovice, Mrzkovice & 1 & $\mathrm{~F} 2$ & $\mathrm{~A}, \mathrm{D}$ & $-1-$ & WA/Vfz \\
\hline
\end{tabular}




\section{References}

1. Snow, J.T.; Wyatt, A.L. Back to basics: The tornado, nature's most violent wind: Part 1-World-wide occurrence and categorisation. Weather 1997, 52, 298-304. [CrossRef]

2. Snow, J.T.; Wyatt, A.L. Back to basics: The tornado, nature's most violent wind: Part 2-Formation and current research. Weather 1998, 53, 66-72. [CrossRef]

3. Brooks, H.E.; Lee, J.W.; Craven, J.P. The spatial distribution of severe thunderstorm and tornado environments from global reanalysis data. Atmos. Res. 2003, 67-68, 73-94. [CrossRef]

4. Moore, T.W. Seasonal frequency and spatial distribution of tornadoes in the United States and their relationship to the El Niño/Southern Oscillation. Ann. Am. Assoc. Geogr. 2019, 109, 1033-1051. [CrossRef]

5. Verbout, S.M.; Brooks, H.E.; Leslie, L.M.; Schultz, D.M. Evolution of the U.S. tornado database: 1954-2003. Weather Forecast. 2006, 21, 86-93. [CrossRef]

6. Brooks, H.E.; Carbin, G.W.; Marsh, P.T. Increased variability of tornado occurrence in the United States. Science 2014, 346, 349-352. [CrossRef]

7. Benjamin, A.E.; Leathers, D.J. Synoptic climatology of tornadoes in the northeast USA. Clim. Res. 2017, 72, 19-27. [CrossRef]

8. Moore, T.W. Annual and seasonal tornado trends in the contiguous United States and its regions. Int. J. Climatol. 2018, 38, 1582-1594. [CrossRef]

9. Bikos, D.; Finch, J.; Case, J.L. The environment associated with significant tornadoes in Bangladesh. Atmos. Res. 2016, 167, 183-195. [CrossRef]

10. Chen, J.; Cai, X.; Wang, H.; Kang, L.; Zhang, H.; Song, Y.; Zhu, H.; Zheng, W.; Li, F. Tornado climatology of China. Int. J. Climatol. 2018, 38, 2478-2489. [CrossRef]

11. Dotzek, N. An updated estimate of tornado occurrence in Europe. Atmos. Res. 2003, 67-68, 153-161. [CrossRef]

12. Groenemeijer, P.; Kühne, T. A climatology of tornadoes in Europe: Results from the European Severe Weather Database. Mon. Weather Rev. 2014, 142, 4775-4790. [CrossRef]

13. Grieser, J.; Terenzi, F. Modeling financial losses resulting from tornadoes in European countries. Weather Clim. Soc. 2016, 8, 313-326. [CrossRef]

14. Antonescu, B.; Schultz, D.M.; Holzer, A.; Groenemeijer, P. Tornadoes in Europe: An underestimated threat. Bull. Am. Meteorol. Soc. 2017, 98, 713-728. [CrossRef]

15. Antonescu, B.; Schultz, D.M.; Ricketts, H.M.A.M.; Ene, D. Theories on tornado and waterspout formation in Ancient Greece and Rome. Weather Clim. Soc. 2019, 11, 889-900. [CrossRef]

16. Wegener, A. Wind- und Wasserhosen in Europa; Friedr. Vieweg \& Sohn: Braunschweig, Germany, 1917.

17. Wegener, A. Windhose im Mürztal vom 11. Mai 1910. Das Wetter 1916, 33, 91-92.

18. Dörr, J.N. Die Windhose von Wiener-Neustadt am 10. Juli 1916. Meteorol. Z. 1917, 34, 1-14.

19. Pühringer, A. Die Windhose im nördlichen Waldviertel vom 19. August 1966. Wetter Leben 1971, 23, 150-159.

20. Pühringer, A. Windhosen in Österreich. Wetter Leben 1973, 25, 15-22.

21. Meaden, G.T. Tornadoes in Britain: Their intensities and distribution in space and time. J. Meteorol. 1976, 1, 242-251.

22. Elsom, D.M.; Meaden, G.T. Spatial and temporal distributions of tornadoes in the United Kingdom 1960-1982. Weather 1984, 39, 317-323. [CrossRef]

23. Dessens, J.; Snow, J.T. Tornadoes in France. Weather Forecast. 1989, 4, 110-132. [CrossRef]

24. Reynolds, D.J. European tornado climatology, 1960-1989. J. Meteorol. 1999, 24, 376-403.

25. Groenemeijer, P.H.; Van Delden, A. Sounding-derived parameters associated with large hail and tornadoes in the Netherlands. Atmos. Res. 2007, 83, 473-487. [CrossRef]

26. Brooks, H.E. Proximity soundings for severe convection for Europe and the United States from reanalysis data. Atmos. Res. 2009, 93, 546-553. [CrossRef]

27. Kaltenböck, R.; Diendorfer, G.; Dotzek, N. Evaluation of thunderstorm indices from ECMWF analyses, lightning data and severe storm reports. Atmos. Res. 2009, 93, 381-396. [CrossRef]

28. Púčik, T.; Groenemeijer, P.; Rýva, D.; Kolář, M. Proximity soundings of severe and nonsevere thunderstorms in Central Europe. Mon. Weather Rev. 2015, 143, 4805-4821. [CrossRef]

29. Taszarek, M.; Brooks, H.E.; Czernecki, B. Sounding-derived parameters associated with convective hazards in Europe. Mon. Weather Rev. 2017, 145, 1511-1528. [CrossRef] 
30. Hannesen, R.; Dotzek, N.; Gysi, H.; Beheng, K.D. Case study of a tornado in the Upper Rhine valley. Meteorol. Z. 1998, 7, 163-170. [CrossRef]

31. Holzer, A.M. Untersuchung und Dokumentation von zwei Tornados in der südlichen Steiermark im Sommer 1998. Wetter Leben 2000, 50, 103-114.

32. Kolendowicz, L. Occurrence of devastating T7-T8 tornado (Traba Powietrzna) in Poland, 29 May 2001. J. Meteorol. 2002, 27, 204-206.

33. Gayá, M. The 1886 tornado of Madrid. Atmos. Res. 2007, 83, 201-210. [CrossRef]

34. Wesolek, E.; Mahieu, P. The F4 tornado of August 3, 2008, in Northern France: Case study of a tornadic storm in a low CAPE environment. Atmos. Res. 2011, 100, 649-656. [CrossRef]

35. Antonescu, B.; Fairman, J.G., Jr.; Schultz, D.M. What is the worst that could happen? Reexamining the 24-25 June 1967 tornado outbreak over Western Europe. Weather Clim. Soc. 2018, 10, 323-340. [CrossRef]

36. Holzer, A.M.; Schreiner, T.M.E.; Púčik, T. A forensic re-analysis of one of the deadliest European tornadoes. Nat. Hazards Earth Syst. Sci. 2018, 18, 1555-1565. [CrossRef]

37. Holzer, A.M. Tornado climatology of Austria. Atmos. Res. 2001, 56, 203-211. [CrossRef]

38. Tyrrell, J. A tornado climatology for Ireland. Atmos. Res. 2003, 67-68, 671-684. [CrossRef]

39. Sioutas, M.V. A tornado and waterspout climatology for Greece. Atmos. Res. 2011, 100, 344-356. [CrossRef]

40. Kirk, P.J. An updated tornado climatology for the UK: 1981-2010. Weather 2014, 69, 171-175. [CrossRef]

41. Taszarek, M.; Brooks, H.E. Tornado climatology of Poland. Mon. Weather Rev. 2015, 143, 702-717. [CrossRef]

42. Dotzek, N. Tornadoes in Germany. Atmos. Res. 2001, 56, 233-251. [CrossRef]

43. Paul, F. A developing inventory of tornadoes in France. Atmos. Res. 2001, 56, 269-280. [CrossRef]

44. Bissoli, P.; Grieser, J.; Dotzek, N.; Welsch, M. Tornadoes in Germany 1950-2003 and their relation to particular weather conditions. Glob. Planet. Chang. 2007, 57, 124-138. [CrossRef]

45. Gayá, M.; Llasat, M.-C.; Arús, J. Tornadoes and waterspouts in Catalonia (1950-2009). Nat. Hazards Earth Syst. Sci. 2011, 11, 1875-1883. [CrossRef]

46. Antonescu, B.; Bell, A. Tornadoes in Romania. Mon. Weather Rev. 2015, 143, 689-701. [CrossRef]

47. Miglietta, M.M.; Matsangouras, I.T. An updated "climatology" of tornadoes and waterspouts in Italy. Int. J. Climatol. 2018, 38, 3667-3683. [CrossRef]

48. Antonescu, B.; Schultz, D.M.; Lomas, F.; Kühne, T. Tornadoes in Europe: Synthesis of the observational datasets. Mon. Weather Rev. 2016, 144, 2445-2480. [CrossRef]

49. Mendel, G. Die Windhose vom 13. October 1870. Verh. Nat. Ver. Brünn Abh. 1871, 9, 229-246.

50. Stöhr, A. Die Windhose von Sicht in Böhmen am 23. April 1904. Das Wetter 1919, 36, 60-64.

51. Fikar, J. Větrná smršt' dne 20. dubna 1950 (Tornado on 20 April 1950). Meteorol. Zpr. 1950, 4, 80-82.

52. Pech, J. Tornádo ve Všerubské vrchovině (The tornado in the Všerubská vrchovina Highlands). In Geografický výzkum v Československé Akademii věd 1952-1982; Geografický ústav ČSAV: Liblice, Czech Republic, 1983; pp. 70-73.

53. Munzar, J. Tromby (tornáda) na území České republiky v letech 1119-1993 (Whirlwinds (tornadoes) in the Czech Republic territory in the years 1119-1993). In Zbornik dejín Fyziky XI.; Vojenská akadémia SNP: Liptovský Mikuláš, Slovakia, 1993; pp. 69-72.

54. Munzar, J. Atmospheric hazards in the Czech Republic: Spouts (tornadoes) as a case study. Stud. Geograph. 1995, 98, 57-64.

55. Š́lek, M. Výskyt tornáda v obci Studnice dne 19. dubna 2000 (Tornado occurrence at the Studnice settlement on 19 April 2000). Meteorol. Zpr. 2001, 54, 8-15.

56. Š́lek, M. Tornádo v Litovli 9. června 2004 (The tornado at Litovel on 9 June 2004). Meteorol. Zpr. 2004, 57, 122-123.

57. Setvák, M.; Novák, P.; Šálek, M. Tornáda 31. května na území České republiky (Tornadoes on 31 May 2001 on the territory of the Czech Republic). Meteorol. Zpr. 2004, 57, 101-112.

58. Setvák, M.; Śálek, M.; Munzar, J. Tornadoes within the Czech Republic: From early medieval chronicles to the "internet society". Atmos. Res. 2003, 67-68, 589-605. [CrossRef]

59. Dobrovolný, P.; Brázdil, R. Documentary evidence on strong winds related to convective storms in the Czech Republic since AD 1500. Atmos. Res. 2003, 67-68, 95-116. [CrossRef]

60. Brázdil, R.; Dobrovolný, P.; Štekl, J.; Kotyza, O.; Valášek, H.; Jež, J. History of Weather and Climate in the Czech Lands VI: Strong Winds; Masaryk University: Brno, Czech Republic, 2004. 
61. Brázdil, R.; Chromá, K.; Dobrovolný, P.; Černoch, Z. The tornado history of the Czech Lands, AD 1119-2010. Atmos. Res. 2012, 118, 193-204. [CrossRef]

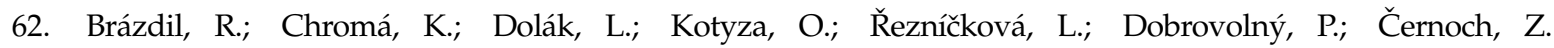
Spatiotemporal variability of tornadoes in the Czech Lands, 1801-2017. Theor. Appl. Climatol. 2019, 136, 1233-1248. [CrossRef]

63. Brázdil, R.; Chromá, K.; Řehoř, J.; Zahradníček, P.; Dolák, L.; Řezníčková, L.; Dobrovolný, P. Potential of documentary evidence to study fatalities of hydrological and meteorological events in the Czech Republic. Water 2019, 11, 2014. [CrossRef]

64. Brázdil, R.; Pfister, C.; Wanner, H.; von Storch, H.; Luterbacher, J. Historical climatology in Europe-The state of the art. Clim. Chang. 2005, 70, 363-430. [CrossRef]

65. Brázdil, R.; Dobrovolný, P.; Luterbacher, J.; Moberg, A.; Pfister, C.; Wheeler, D.; Zorita, E. European climate of the past 500 years: New challenges for historical climatology. Clim. Chang. 2010, 101, 7-40. [CrossRef]

66. Fujita, T.T. Tornadoes around the world. Weatherwise 1973, 26, 56-83. [CrossRef]

67. Fujita, T.T. Tornado and downbursts in the context of generalized planetary scales. J. Atmos. Sci. 1981, 38, 1511-1534. [CrossRef]

68. Meaden, G.T.; Rowe, M. The work of the tornado and storm research organisation: Tornadoes as weather hazard in Britain. Int. J. Meteorol. 2006, 31, 237-242.

69. The TORnado and storm Research Organisation. The International Tornado Intensity Scale. Available online: http://www.torro.org.uk/tscale.php (accessed on 15 April 2020).

70. Doswell, C.A., III; Brooks, H.E.; Dotzek, N. On the implementation of the enhanced Fujita scale in the USA. Atmos. Res. 2009, 93, 554-563. [CrossRef]

71. Z Velké Střelné. Našinec, 7 July 1932; evening edition. 3. (In Czech)

72. Státní okresní archiv Opava, fond Archiv obce Milostovice, inv. č. 27 Pamětní kniha obce Milostovic, 1926-1945. Unpublished work.

73. Škody zpo̊sobené tornádem v Milostovicích 21. června 1932 (Okres Opava) (Damage Caused by the Tornado on 21 June 1932 at Milostovice in the Opava District). Available online: http://dobrmanek.rajce.idnes.cz/ tornado_v_Milostovicich/ (accessed on 27 March 2020).

74. Hess, P.; Brezowsky, H. Katalog der Grosswetterlagen Europas; Berichte des Deutschen Wetterdienstes in der U. S. Zone 33; Deutscher Wetterdienst in d. U. S. Zone: Bad Kissingen, Germany, 1952.

75. Werner, P.C.; Gerstengarbe, F.-W. Katalog der Großwetterlagen Europas (1881-2009) nach Paul Hess und Helmut Brezowsky. 7, Verbesserte und ergänzte Auflage; PIK Report No. 119; Potsdam-Institut für Klimafolgenforschung: Potsdam, Germany, 2010.

76. Deutscher Wetterdienst. Großwetterlage 2018. Available online: https://www.dwd.de/DE/leistungen/ grosswetterlage/2018/grosswetterlage.html?nn=161022003-2020 (accessed on 17 April 2020).

77. Kolektiv Pracovníků Synoptické a Letecké Služby HMÚ. Katalog Povětrnostních Situací pro území ČSSR (Catalogue of Weather Situations over the Territory of the C.S.S.R.); HMÚ: Praha, Czech Republic, 1967.

78. Český Hydrometeorologický ústav. Typizace Povětrnostních Situací pro území České Republiky (Classification of Weather Situations for the Territory of the Czech Republic). Available online: http: //portal.chmi.cz/historicka-data/pocasi/typizace-povetrnostnich-situaci (accessed on 10 April 2020).

79. Křivancová, S.; Vavruška, F. Základní Meteorologické Proky v Jednotlivých Povětrnostních Situacích na území České Republiky v Období 1961-1990 (Basic Meteorological Elements in Individual Weather Situations over the Territory of the Czech Republic in the 1961-1990 Period); Národní klimatický program Česká republika 27; Český Hydrometeorologický ústav: Praha, Czech Republic, 1997.

80. Doswell, C.A., III; Brooks, H.E.; Maddox, R.A. Flash flood forecasting: An ingredients-based methodology. Weather Forecast. 1996, 11, 560-581. [CrossRef]

81. Smith, B.T.; Thompson, R.L.; Grams, J.S.; Broyles, C.; Brooks, H.E. Convective modes for significant severe thunderstorms in the Contiguous United States. Part I: Storm classification and climatology. Weather Forecast. 2012, 27, 1114-1135. [CrossRef]

82. Weisman, M.L.; Klemp, J.B. The dependence of numerically simulated convective storms on vertical wind shear and buoyancy. Mon. Weather Rev. 1982, 110, 504-520. [CrossRef]

83. Thompson, R.L.; Edwards, R.; Hart, J.A.; Elmore, K.L.; Markowski, P. Close proximity soundings within supercell environments obtained from the rapid update cycle. Weather Forecast. 2003, 18, 1243-1261. [CrossRef] 
84. Trapp, R.J.; Stumpf, G.J.; Manross, K.L. A reassessment of the percentage of tornadic mesocyclones. Weather Forecast. 2005, 20, 680-687. [CrossRef]

85. Markowski, P.M.; Richardson, Y.P. The influence of environmental low-level shear and cold pools on tornadogenesis: Insights from idealized simulations. J. Atmos. Sci. 2014, 71, 243-275. [CrossRef]

86. Guarriello, F.; Nowotarski, C.J.; Epifanio, C.C. Effects of the low-level wind profile on outflow position and near-surface vertical vorticity in simulated supercell thunderstorms. J. Atmos. Sci. 2018, 75, 731-753. [CrossRef]

87. Rasmussen, E.N.; Blanchard, D.O. A baseline climatology of sounding-derived supercell and tornado forecast parameters. Weather Forecast. 1998, 13, 1148-1164. [CrossRef]

88. Rasmussen, E.N. Refined supercell and tornado forecast parameters. Weather Forecast. 2003, 18, 530-535. [CrossRef]

89. Craven, J.P.; Brooks, H.E. Baseline climatology of sounding derived parameters associated with deep, moist convection. Natl. Weather Dig. 2004, 28, 13-24.

90. Nowotarski, C.J.; Jensen, A.A. Classifying proximity soundings with self-organizing maps toward improving supercell and tornado forecasting. Weather Forecast. 2013, 28, 783-801. [CrossRef]

91. Coffer, B.E.; Parker, M.D. Is there a "tipping point" between simulated nontornadic and tornadic supercells in VORTEX2 environments? Mon. Weather Rev. 2018, 146, 2667-2693. [CrossRef]

92. Hersbach, H.; Dee, D. ERA5 reanalysis is in production. ECMWF Newsl. 2016, 147, 56.

93. Doswell, C.A., III; Rasmussen, E.N. The Effect of Neglecting the Virtual Temperature Correction on CAPE Calculations. Weather Forecast. 1994, 9, 625-629. [CrossRef]

94. Bunkers, M.J.; Klimowski, B.A.; Zeitler, J.W.; Thompson, R.L.; Weisman, M.L. Predicting supercell motion using a new hodograph technique. Weather Forecast. 2000, 15, 61-79. [CrossRef]

95. Johns, R.H.; Doswell III, C.A. Severe local storms forecasting. Weather Forecast. 1992, 7, 588-612. [CrossRef]

96. Grams, J.S.; Thompson, R.L.; Snively, D.V.; Prentice, J.A.; Hodges, G.M.; Reames, L.J. A climatology and comparison of parameters for significant tornado events in the United States. Weather Forecast. 2012, 27, 106-123. [CrossRef]

97. Gensini, V.A.; Mote, T.L.; Brooks, H.E. Severe-thunderstorm reanalysis environments and collocated radiosonde observations. J. Appl. Meteorol. Climatol. 2014, 53, 742-751. [CrossRef]

98. Taszarek, M.; Brooks, H.E.; Czernecki, B.; Szuster, P.; Fortuniak, K. Climatological aspects of convective parameters over Europe: A comparison of ERA-Interim and sounding data. J. Clim. 2018, 31, 4281-4308. [CrossRef]

99. Bretholz, B. (Ed.) Die Chronik der Böhmen des Cosmas von Prag. In Monumenta Germaniae Historica, Scriptores Rerum Germanicarum; Nova Series 2; Weidmann: Berlin, Germany, 1923.

100. Moravský zemský archiv v Brně, fond G 13 Sbírka Historického spolku Brno, inv. č. 199 Kronika města Fulneku. Unpublished work.

101. Ǩádění smršti v severních Čechách. Lidové Noviny, 3 October 1900; 6. (In Czech)

102. Větrné smrště v Čechách. Národní Listy, 26 April 1904; 3. (In Czech)

103. Davies, J.M. Tornadoes in environments with small helicity and/or high LCL heights. Weather Forecast. 2006, 21, 579-594. [CrossRef]

104. Markowski, P.M.; Straka, J.M.; Rasmussen, E.N.; Blanchard, D.O. Variability of storm-relative helicity during VORTEX. Mon. Weather Rev. 1998, 126, 2959-2971. [CrossRef]

105. Bluestein, H.B. Tornado Alley. Monster Storms of the Great Plains; Oxford University Press: New York, NY, USA; Oxford, UK, 1999.

106. Lyza, A.W.; Knupp, K.R. A background investigation of tornado activity across the Southern Cumberland Plateau terrain system of Northeastern Alabama. Mon. Weather Rev. 2018, 146, 4261-4278. [CrossRef]

107. Taszarek, M.; Gromadzki, J. Deadly tornadoes in Poland from 1820 to 2015. Mon. Weather Rev. 2017, 145, 1221-1243. [CrossRef]

108. Groenemeijer, P.; Púčik, T.; Holzer, A.M.; Antonescu, B.; Riemann-Campe, K.; Schultz, D.M.; Kühne, T.; Feuerstein, B.; Brooks, H.E.; Doswell, C.A., III; et al. Severe convective storms in Europe: Ten years of research and education at the European Severe Storms Laboratory. Bull. Am. Meteorol. Soc. 2017, 98, 2641-2651. [CrossRef] 
(C) 2020 by the authors. Licensee MDPI, Basel, Switzerland. This article is an open access article distributed under the terms and conditions of the Creative Commons Attribution (CC BY) license (http://creativecommons.org/licenses/by/4.0/). 